\title{
Design Framework for A School Playground
}

\author{
Syaiputra Wahyuda Meisa Diningrat $\bowtie$ \\ Pendidikan Islam Anak Usia Dini, Sekolah Tinggi Ilmu Tarbiyah Galis Bangkalan
}

\begin{abstract}
Playing in outdoor learning environment is pivotal to the life of children. Allowing them to interact with playground promise the children to enhance their well-being and healthy growth and development. Experts believe in capabilities of playground on supporting not only the children's growth, but also the children's development. In contrast, research showed lack of appropriateness playground with the children's need become the hardest challenge for some educators. Therefore, this study aims to provide theoretical framework in design a school playground that fits with the children's needs. The methodology used for this study has been done through analyze the recent literature such as books, journals and research related to design playground. The study has attempted to answer questions such as principles of playground design, causes of children's use the playground and the design framework for playground that suitable for children's needs. In summary, this article will facilitate educators to design higher quality playground that fit with the needs of the children. Thus, it is recommended for educators to use design framework for a school playground in order to minimize the failure in design and develop playground. Therefore, the effort to facilitate the children's growth and development through a playground become effectively.
\end{abstract}

Keywords: design playground; effectiveness; early childhood

\begin{abstract}
Abstrak
Bermain di playground merupakan hal penting bagi kehidupan anak. Berkesempatan interaksi dengan playground memberikan harapan anak untuk dapat meningkatkan kesejahteraan dan tumbuh kembang yang sehat. Para ahli percaya pada kemampuan playground yang tidak hanya dapat mendorong pertubuhan anak usia dini, akan tetapi juga dapat mendorong perkembangannya. Sebaliknya, penelitian menunjukkan bahwa ketidaksesuaian playground dengan kebutuhan anak usia dini masih menjadi tantangan terberat bagi para guru. Oleh karean itu, kajian ini bertujuan untuk menyediakan kerangka teoritik dalam merancang playground yang sesuai dengan kebutuhan anak. Metode yang digunakan dalam mengkaji artikel ini telah dilakukan melalui analisis literatur terbaru pada buku-buku yang membahas tentang playground, jurnal, dan penelitian yang telah dilakukan yang berkaitan dengan playground. Kajian pada artikel ini mencoba untuk menjawab beberapa pertanyan seperti prinsipprinsip dalam desain playground, sebab-sebab anak usia dini mau menggunakan playground, dan kerangka desain playground yang sesuai dengan kebutuhan anak usia dini. Kesimpulannya, artikel ini akan mempermudah pendidik dalam mendesain playground berkualitas dan sesuai kebutuhan anak, maka direkomendasikan kepada para pendidik untuk menggunakan kerangka desain playground untuk sekolah dengan tujuan meminimalisir kegagalan dalam merancang dan mengembangkan playground sehingga upaya memfasilitasi pertumbuhan dan perkembangan anak usia dini melalui playground menjadi efektif.
\end{abstract}

Kata Kunci: desain area bermain di luar kelas; efektivitas; anak usia dini.

@Jurnal Obsesi Prodi PG-PAUD FIP UPTT 2019

$\triangle$ Corresponding author :

Address : Bulak Rukem, Surabaya

Email : syaiputrawmd@gmail.com

ISSN 2356-1327 (Media Cetak)

ISSN 2549-8959 (Media Online) 


\section{INTRODUCTION}

The basic form of outdoor learning environment is playful, physical activity, as well as exploration and discovery the environment (Ebbeck, Yim, \& Warrier, 2019). It means playful and physical activities become a foundation for design an effective playground for early childhood. In other words, these foundations could be taken into consideration in designing playground.

Even though playground is closely to physical activity, it could be as effective as indoor setting in enhancing young children's development in all domains (Ernst, 2014), such as cognitive, social/emotional (Pica, 2008), language (Susilowati, 2014), and multiple intelligences (Mariyana \& Setiasih, 2018). Therefore, it could be concluded that playground has significant benefits to promote children's growth and development.

These concludes are supported by the study of types of experience in playground and modes of learning in childhood development (see figure 1). Children experiences with the playground appear to be in three different type of use such as direct, indirect and symbol or imaginary. Meanwhile, there are three modes of learning in childhood such as cognitive refers to thinking and problem-solving skills, emotional refers to feeling and emotion, as well as moral refers to value, benefits and moral aspects (adapted from Kellert in (Acar, 2014)).

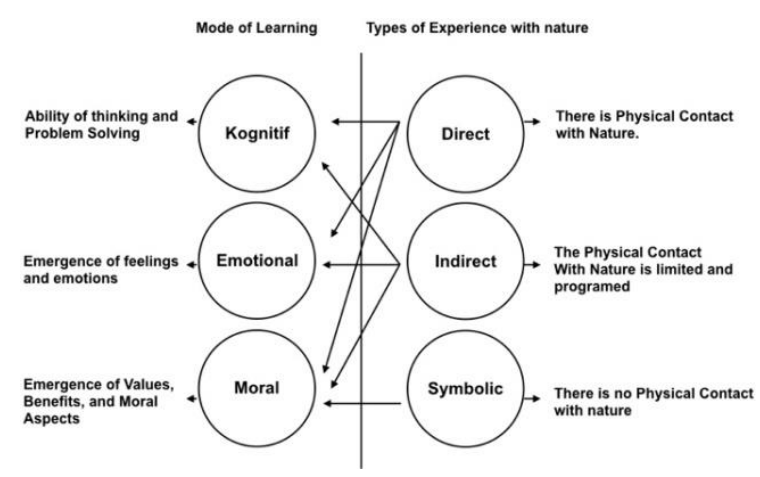

Figure 1: Types of experience in playground and modes of learning in childhood development.

Despite its significances, research indicated that educators face challenges such as lack of providing rich activities and managing an effective playground (Andinna, Fadillah, \& Miranda, 2015); (Nurwidiyawati, 2016), even lack of benefiting awareness about the advantages for children (Willoughby, 2014). As a result, these challenges impact on ineffectiveness playground, less opportunity for children to do and to explore, as well as unsafe of spaces for play.

Additionally, research (Aziz \& Said, 2012) indicated that the following is the most challenging issues regarding to design suitable playground for children.

1. Inappropriate scale in designing space.

2. Needfulness of amenity in designing of edge and entry ways.

3. Sociability spaces for group play.

4. Provide safety for children.

5. Necessity of security for entry of playground.

6. Presence of parents in children spaces.

7. Flexible spaces for participate children.

However, to gain high quality playground design, (Oloumi, Mahdavinejad, \& Namvarrad, 2012) proposed that playground is influenced by children's development needs, individual, physical, and social factors. Thus, it's not only to suggest educators about important considerations, but also to apply into design playground that fits with the 
children's needs. In other words, educators should carefully design with many considerations most importantly related to children, setting and equipment of playground.

Therefore, this article will discuss about how to design an effective playground that fit with the children's needs.

Piaget has proposed fourth stages of cognitive development, it's called cognitive developmental theory (Santrock, 2011), these are: (1) Sensorimotor stage, (2) Preoperational stage, (3) Concrete operational stage and (4) Formal operational stage. Those stages imply that every stage has different way of thinking and understanding of the world. However, we could put the early childhood on the concrete operational stage. Therefore, the way of learning of the early childhood should be through hands on and based on their needs. Similarity, (Mariyana, Nugraha, \& Rachmawati, 2010) said that through concrete experiences and motor activities are the most suitable instructional model that fits with the characteristics of the early childhood. Additionally, experts claim that play should be considered as the heart of the early childhood.

Therefore, one of the most suitable ways to facilitate the growth and development of early childhood is through outdoor learning environment or playground because physically active in playground enhances growth by including a child's whole body in practice and skill development such as run, jump, walk and climb (Perry, 2011). He also argues when children experience active physical exercise in playground, they also experience the cognitive and social demands to think, speak, and negotiate with playmates and teachers.

\section{Playground}

Council for the Curriculum, Examinations and Assessment (CCEA, 2005) stated that the important of playground such as it allows and encourage children to relive their experience through their most natural channel - movement, where movement is one of the four vehicles through which children can learn, it provides access to space to nurture mind-body growth, physical development is the pre-requisite for the children's growth. And playground can enhance the development of motor skills, develop co-ordination, balance and body awareness, keeps the body, heart and other organs healthy, and develops a lifelong good habit of daily exercise, it provides the opportunity for assessed risky freedom, where children can play and socialize freely and use their own imagination and initiative, all the areas of learning can be achieved outside (playground) while the children's longterm social, emotional and mental health are being enhanced, exercise can affect emotions allowing for relaxation and calmness as well as a heightened sense of well-being:

These rational really make sense, such a playground can be a vehicle for children to learn. Due to the capabilities of the playground, it has many possibilities to promote and to enhance children's growth and development.

There are lots of benefits for young children when they can spend as much as time as possible playing outside in interesting outdoor environments. (Willoughby, 2014) stated that playground is not only gives many opportunities for experience with all their senses, physical activities, observations, developing social skills, building and constructing with sand, water, and mud, but also helps children to develop their strength, immunity, language 
and communication skills, as well as learn about decision making and problem solving. Similarity, Education Organization Scotland (Education Scotland, n.d.) showed that there are some general benefits of outdoor learning. Firstly, helping to develop skills, knowledge and understanding in a meaningful context. Secondly, providing rich stimulus for creative thinking and learning. Lastly, developing awareness of the complexities of the real world so that they can develop critical thinking skills.

Based on the benefits of playground, the teachers of early childhood should be encouraged to design and to develop playground that meets with the children's needs. Because the condition in the rural environment and urban environment are different. Thus, in design playground should be relevance with the characteristic of the area and the curriculum, even the children.

\section{Principles in Playground Design.}

In general, (Mariyana et al., 2010), there are four principles in design playground, these are as follow:

1. Safety.

2. Be able to Protect the children.

3. Based on the children's need.

4. Enjoyable.

These general principles should be considered by the educators who interested to design a playground. Foremost the safety, because it becomes an essential factor that decides whether the playground is success or not. However, others principles also important for the consideration both children's needs and enjoyable. it can be possible for children to avoid the playground that not fits with their needs. Thus, the educators really carefully in design playground for children.
In specific, (Bilton, 2010) showed ten principles should be understood by educator, such as indoor and outdoor (playground) need to be viewed as one combine and integrated environment, indoor and playground need to be available to the children simultaneously, playground is an equal player to indoor and should receive planning, management, and evaluation, resourcing, staffing, and an adult interaction on a par with indoor, playground is both a teaching and learning environment, playground design and layout needs careful consideration, playground is central to young children's learning, playground offers children the opportunity to utilize effective modes of learning, children need versatile equipment and environments, children need to be able to control, change and modify their environment as well as staff have to be supportive towards playground

These principles give an educator critical foundation for design playground. Foremost it could be understood that both indoor and outdoor (playground) need to be planned and designed carefully in order to meet with the children's needs, such as access to playground, size, layout, fix equipment, the weather, surface, seating, the look of the area, and storage. Additionally, play is a central part of the children' learning so that educators should put play as a central part of the playground. It can be done by providing children to control, choose, change, and even modify the resources (e.g. sand area, water area, physical area) in the playground.

\section{Types of Areas in Playground}

(Bilton, 2010) identify a number of basic learning bays, these are:

1. an imaginative play area.

2. a building and construction area.

3. a gymnasium area.

4. a small apparatus area. 
5. a horticultural area.

6. an environmental and scientific area.

7. a quite area.

However, those basic learning bays should be alight to these areas of learning and development (Bilton, 2010) namely:

1. Personal, social, and emotional development.

2. Communication, language and literacy.

3. Problem solving, reasoning, and numeracy.

4. Knowledge and understanding of the world.

5. Physical development.

6. Creative development.

\section{Characteristics of a Good Playground}

(White \& Whoolley, 2014) proposed six characteristics of a good playground. Firstly, physically diverse, the studies indicate that when landscape features met children's needs for a stimulating and variety play environment, it's not only positively enhance the level of physical activity, but also children's motor development. In other words, educators should provide as many as possible spaces for play that fits with the children's needs.

Secondly, generous: for enquiry, discovering and thinking. It means the kinds of materials and resources for children should significantly affect the nature of their experiences. Thus, the educators should be able to provide materials and resources they need. However, there are three kinds of generosity such as a rich of an environment, with and abundance of interesting stuff for children to handle; the availability of "big ideas", investigating and making sense of the real world; and an abundant of time for doing and thinking.

Thirdly, supportive: for feeling nurtured, calm, imaginative. A good playground should have provisions of suitable environmental features and qualities such as can support withdrawal, seclusion, downtime, peace, and restoration. However, softness is a characteristic that should pervade the whole playground because the softness in the playground helps to induce a state of calm and contemplation.

Fourthly, secure: For feeling comfortable and at home. Besides physically diverse, generous, supportive, it's critical that the child feels secure. Engagement and motivation occur where the playground feels familiar, makes sense to the child and is easy to use. Therefore, children need to know, understand, and read the playground, and for this to happen it needs to be stable and mappable, to become readable and predictable. However, there are three particular aspects in organization and design that can provide variety within a framework of predictability, enabling young children to harness the richness of the playground. These are transition, storage, and paths. Consideration should be focus on how this transition zone supports children to cross the threshold to go out or to come in, to move easily between inside and outside and to link their play and learning. The way in which resources are stored and made available to children makes a major contribution to familiarity and ease of use. Thus, educators seek to make resources highly visible and accessible as individual items to children. A well link system of pathways can unify all parts of the playground, connecting them physically and spatially, allowing play to flow from place to place and enabling all areas to play their part.

Fifthly, agency: for being in control and feeling powerful. A good playground must meet the individual needs of every child to construct their own play and follow their own enquiries and give them a sense of control and empowerment or 
agency. Flexibility in resources or openness in how the playground can be used and manipulated itself brings higher play value and valuable educational outcomes. To achieve this, educators should provide higher levels of developmental value with more complex social interaction and negotiation; new dimensions of friendship; and more meaningful and sustained play themes. Therefore, agency is considered to be critical component of wellbeing and learning and is vital if children are to become resilient, capable, confident, and self-assure.

Sixthly, connection: for traveling, journey and adventure. Pathways exert a powerful influence on people, particularly children, and play a significant and multifaceted role in how a playground operates. Pathways are often used in role play, perhaps offering imagination, mystery and adventure. Thus, pathways make children move so they can play a powerful role in the pedagogic outdoor environment because they can support several schematic themes commonly seen in the early years, particularly: trajectory schema, where movement in lines, arcs or curves is explored, building the child's ability to think about space and how movement can occur in it. Transporting schema, where children are physically experiencing movement and distance, length travelled and speed, through moving themselves and objects. Going Through schema, with the physical experience of going through and emerging at the other side (particularly in tunnels and bridges). Pathways with junctions and choices could support grid and connecting schematic interests

\section{Factors Influencing children's use of playground}

(Aziz \& Said, 2012) described three main factors that influencing children's use of playground. Such as individual factors, physical factors and social factors. See table 1, as follow:

Table 1: Three main factors influencing children's use of playground.

\begin{tabular}{|c|c|c|}
\hline Category & Main Factors & Descriptions \\
\hline $\begin{array}{l}\text { Individual } \\
\text { factors }\end{array}$ & $\begin{array}{l}\text { - Demographic. } \\
\text { - Socioeconomic status. } \\
\text { - Place's experiences. } \\
\text { - Attitude to active play. }\end{array}$ & $\begin{array}{l}\text { Factors relating to age, gender and ethnic. } \\
\text { The status of family income either they are from low, } \\
\text { medium or high income fmaily. } \\
\text { Children's familiarity with places and spesific experiences } \\
\text { with the places or elements. } \\
\text { Individual preferences and positive and negative attitudes } \\
\text { toward active place and particular play spaces. }\end{array}$ \\
\hline $\begin{array}{l}\text { Physical } \\
\text { Factors }\end{array}$ & $\begin{array}{l}\text { - Design and quality of } \\
\text { facilitaties/play } \\
\text { equipment. } \\
\text { Environemntal factors/ } \\
\text { urban design / safety. } \\
\text { - Level of affordance. }\end{array}$ & $\begin{array}{l}\text { Provision of facilities at public open spaces such as } \\
\text { playgrounds and parks. } \\
\text { Elements of urban design and sreet design which } \\
\text { influence choices of place for active play. } \\
\text { Availability of functional elements in the outdoor } \\
\text { environments. }\end{array}$ \\
\hline $\begin{array}{c}\text { Social } \\
\text { Factors }\end{array}$ & $\begin{array}{l}\text { - Parental restriction and } \\
\text { level of children's } \\
\text { independence. } \\
\text { - Bad people and culture. } \\
\text { - Social Aspects. } \\
\text { - Geographical perspective }\end{array}$ & $\begin{array}{l}\text { Parental fears on the children's safety increased the } \\
\text { restriction to play outside and decreased children's } \\
\text { autonomous mobility. } \\
\text { Exposure to strangers, teenagers and negative cultures. } \\
\text { Impact of friends, peers, neighbours in children's play. } \\
\text { Social interaction between parents in establishing local } \\
\text { norm. }\end{array}$ \\
\hline
\end{tabular}

However, physical factor is emphasized to give a rational related to design an effective playground. Thus, one of the main factors influencing children's use of playground is design, quality of facilities, play equipment, environmental factors or safety and level of affordances.

Overall, it may be said that design an effective playground which appealing and meeting with children's needs is required not only to carefully design with many considerations related to these three factors, but also theoretical framework in designing playground.

Therefore, this article aims to give a design framework for an effective playground. It could be a guidance for educators in designing playground that meets with the needs of the children. Thus, educator who will design playground would be spared from mistakes, so that they are not only able to gain maximum benefits of an effective playground such a provide as much opportunity as possible for children to experience and play freely in playground, but also support the children to be physically active with safety playground. 


\section{METHODOLOGY}

The methodology used for this study has been done through analyze the recent literature such as books, journals and research related to design playground. Therefore, data would be collected by available literature and analysis data is conducted through descriptively.

The objectives of this study were to recognize how to design an effective playground that fit with the children's needs. The study has attempted to answer the following question: what the principle of playground design?, what the cause children's use of playground?, what the design framework for playground that most suitable for children's needs?

However, the answer from question one to two has described in the literature review above. Therefore, the last question would be described in the result section.

\section{RESULT AND DISCUSSION}

When considering a good playground design for the children this article suggests, informed by Casey (Casey, 2007) model design, the key stages in designing a playground see figure 3 . Briefly analysis, as follow:

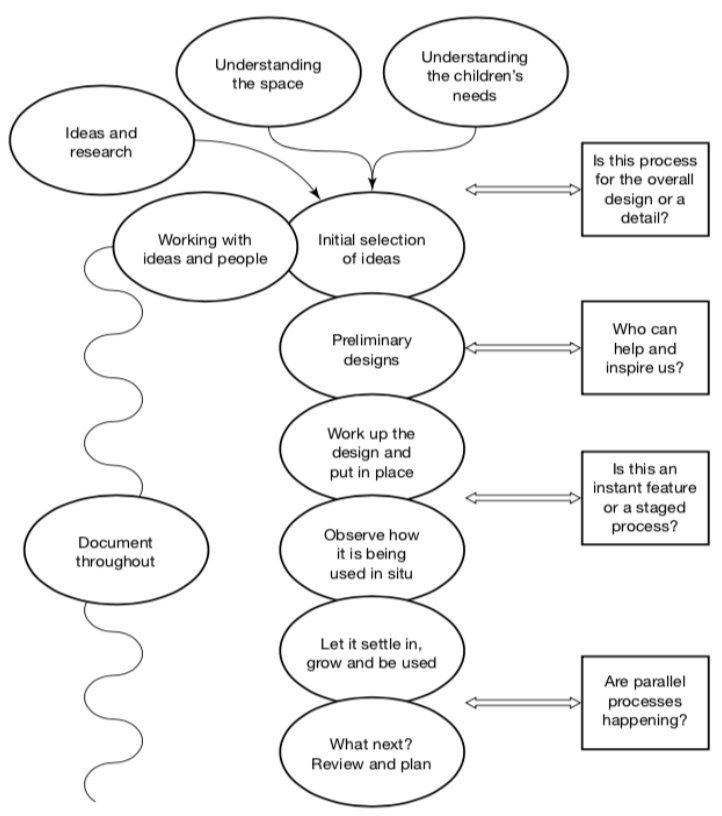

Figure 3: Key Stage Design Playground

\section{Understanding the children's needs.}

It can be considered as a vital part in these steps, however, to achieve the need of children educator should engage with them early on. Therefore, this step will give an educator important information from the children's needs that will be translated into the design playground

\section{Understanding the space.}

After identified the needs of the children, the next step is to see deeper about the available space. It will bring the educator to have a deeper understanding about how to design playground based on the appropriateness of the available space, because every school have different space. However, to make a good playground design can be reached by direct observation, conversation with children or local adults, research and advice from an expert.

\section{Ideas and research.}

At this step is going to bring the educator into rich and inclusive playground design. To identify the features and elements which will provide children with enriching opportunities for play educator should consider the factors that contribute to successful playground, these are; provide opportunities for a varied and interesting physical environment, provide opportunities for challenge in relation to the physical environment, provide opportunities for playing with natural elements- earth or water, provide opportunities for movement for example running or jumping, provide opportunities for manipulating natural materials, provide opportunities for stimulation of the five senses, provide opportunities for social interaction, and provide opportunities for experiencing a range of emotion. 


\section{Working with ideas and people.}

At this step focuses on the collaboration from many experts such as craftspeople, landscape architects, architects, carpenters and builders, council officer, volunteers and playworker, play equipment manufacturers, even instructional designers to offer their ideas related to playground design, for example selecting semi-permanent or temporary features, what spaces would be offered, and how much spaces would be used, and also how to make a good design of playground).

\section{Initial selection ideas.}

After produces an abundance of ideas and suggestion from many experts, the next step is to filter through these ideas and making some of selections and decisions that will work in the particular spaces or spaces identified. So that, educators will choose the most appropriateness playground design with the children's need and available spaces. To simplify this step, educators should consider these factors:

1. Finances and resources available.

2. Compatibility with the location.

3. Making the right play environment for the users.

4. The development of a coherent design.

5. A realistic and sustainable plan.

\section{Preliminary design.}

At this step educators should consider the entire concept into initial draft design of sites in a playground. However, initial design playground could be assisted by drawing whether using manual or computer and sketching.

In additional, Casey suggests educators when they are designed draft playground to remember these questions, such as flow around the site - is the draft design give an away for the children to move from one play area to another, relationships between areas, potential for change, it means that is the design area flexible enough to carter for additions and adaptations over time, scale - are variation in scale making best use of outdoor space? and setting - does the design relate comfortably to its surroundings?, as well as accessibility - are there a number of ways to navigate the space and access various areas? Are the entrances and exits suitable, especially for families and people using wheelchairs?

\section{Work up the design and put it in place.}

Action planning and project management are the characteristics of this stage such as what needs to happen, when should it happen, who is responsible, to what timeframe and at what cost

However, each task above could be broken down into initial arrangements to be made (e.g. ordering materials), task on site (e.g. building or installing), and follow up arrangements (e.g. maintenance checks)

Additionally, the elements of the overall design can be done in different ways. For some parts of it you may be better of bringing in a specialist rather than economizing, whereas there may be parts of the plan which can be achieved by working with a team of volunteers. Some elements can be built by children and staff or parents together.

The last three steps are not used in this study because of its different part. These are:

1. Observe how it is being used in site.

2. Let it settle in growth and be used.

3. What next? Review and plan.

The steps above become parts of the development stages. Thus, in this study those steps will not whether used or analyzed. 


\section{CONCLUTION}

Facilitating the children's growth and development effectively are required design framework that could provide appropriateness of the needs of the children. It's obvious that high quality in design playground encourage the children to use and play so that children's growth and development could be maximum.

This article has provided design framework as a guidance for educators who interested to design an effective playground. This guidance not only capable to facilitate educator in design a playground, but also capable to produce high quality in designing playground.

One of the main reasons that support to produce an effective design playground is the existing stages of understanding the children's needs and understanding the available space. As a result, this design framework will produce not only an effective design playground, but also produce appropriateness principles with every children, spaces, social, and school condition. Therefore, it is recommended for educators, even instructional designers to use design framework for a school playground in order to minimize the mistake might have in design and develop playground.

\section{ACKNOWLEDGEMENTS}

The author thanks to journal of Obsesi that has facilitated author's article to publish as well as to editors for the technical assistance.

\section{REFERENCES}

Acar, H. (2014). Learning environments for children in outdoor space. Procedia Social and Behavioral Sciences, 141, 846-853.

Andinna, Fadillah, \& Miranda. (2015). Analisis Pengelolaan Area Bermain
Outdoor Pada Anak Usia 4-5 Tahun di TK LKIA Pontianak. Jurnal Pendidikan Dan Pembelajaran, 4(11).

Aziz, \& Said. (2012). The Trends and Influential Factors of Children's Use of Outdoor Environments: A Review. Procedia Social and Behavioral Sciences, 38, 204-212.

Bilton, H. (2010). Outdoor Learning in the Early Years: Management and Innovation (Third Edit). New York: Routledge.

Casey, T. (2007). Environments for Outdoor Play: A Practical Guide to Making Space for Children. California: Chapman Publishing.

CCEA. (2005). Learning Outdoor in The Early Years: A Resource Book. Retrieved March 1, 2019, from http://www.nicurriculum.org.uk/docs /foundation_stage/learning_outdoors. pdf

Ebbeck, Yim, \& Warrier. (2019). Early Childhood Teacher's Views and Teaching Practices Outdoor Play with Young Children in Singapore. Early Childhood Education Journal, 47(03).

Education Scotland. (n.d.). Outdoor Learning: Practical Guidance, Ideas and Support. Retrieved March 18, 2019 , from https://education.gov.scot/improvem ent/documents/hwb24-ol-support.pdf

Ernst, J. (2014). Early Childhood Educators' Preferences and Perceptions Regarding Outdoor Setting as Learning Environments. International Journal of Early Childhood Environmental Education, 02(01).

Mariyana, Nugraha, \& Rachmawati. (2010). Pengelolaan Lingkungan Belajar. Jakarta: Kencana.

Mariyana, R., \& Setiasih. (2018). Desain 
336 | Design Framework for A School Playground

$\begin{array}{ll}\begin{array}{l}\text { Lingkungan Belajar } \quad \text { untuk } \\ \text { Mengoptimalkan }\end{array} & \text { website: } \\ \text { Intelligences Anak Usia Dini. Jurnal } & \text { https://www.galwaychildcare.com/up } \\ \text { Pendidikan Usia Dini, 12(21). } & \text { loadedfiles/Outdoor_Play_Matters.p }\end{array}$

Nurwidiyawati, A. (2016). Deskriptif

Penyediaan Lingkungan Outdoor

Sebagai Penunjang Aktivitas

Bermain Anak Di PAUD Kecamatan

Tumijajar Kabupaten Tulang

Bawang Jawa Barat. Retrieved

March 11, 2019, from Skripsi

website:

http://digilib.unila.ac.id/23768/3/SK

RIPSI TANPA BAB

PEMBAHASAN.pdf

Oloumi, Mahdavinejad, \& Namvarrad.

(2012). Evaluation of Outdoor

Environment from The Viewpoint of

Children. Procedia Social and

Behavioral Sciences, 35, 431-439.

Perry, J. (2011). Outdoor Play. In Hoorn et all (Ed.), Play at the Center of the Curriculum (5th ed.). London: Pearson.

Pica, R. (2008). Take it Outside. Retrieved March 3, 2019, from EarlychildhoodNews website: http://www.earlychildhoodnews.com /earlychildhood/article_view.aspx?A rticleID $=275$

Santrock, J. (2011). Child Development (Thirteenth). New York: McGraw Hill Companies.

Susilowati, R. (2014). Strategi Belajar Out Door Bagi Anak PAUD. Thufula, 02(01).

White, J., \& Whoolley, H. (2014). What Makes a Good Outdoor Environment for Young Children. In Trisha \& Waters (Eds.), Exploring Outdoor Play in the Early Years. New York: Open University Press.

Willoughby, M. (2014). Outdoor Play Matters: The Benefits of Outdoor Play for Young Children. Retrieved March 2, 2019, from Barnardos 